\title{
Sustainable New Towns and Transportation Planning; Reflection of A Case Study
}

\author{
Abdol Aziz Shahraki* \\ Department of Regional studies, Royal Institute of Technology, Sweden
}

*Corresponding author: Abdol Aziz Shahraki, Department of Regional studies, The Royal Institute of Technology, KTH, the School of Architecture and the Built Environment, Department of Regional Studies, Stockholm, Sweden, Email: sharaki@kth.se

Submission: 眥 March 24, 2018; Published: 眥July 09, 2018

\begin{abstract}
This paper discusses the link between sustainable development and transportation networks. The paper criticizes the current planning development ways, which exclude sufficient regional and urban traffic infrastructures.The paper aims to investigate the various effects of a regional corridor and on the new towns' capacity to home increasing regional population. The paper analyses the obstacles that hinder the realization of the target to build sustainable new towns with the help of academic theoretical method and with the strategy of a case study.This paper builds a model of the transportation network to remedy the current failures. The model contributes to the new towns in similar situations in the world to become sustainable and attractive.
\end{abstract}

Keywords: Regional transportation; Corridor;Urban traffic;Fluent flow;Development;Ramshar; Iran

\section{Introduction}

Imagine you live in a developing region there the population is growing rapidly and there is a demand for more urban neighborhoods. Therefore, you must build new homes and towns for emergency without the necessary urban and regional traffic networks. You always see congested avenues and passages and the traffic flow is jammed. At the same time, the new towns are neither satisfactory for residents nor gorgeous objects for investors and tourists. You believe that your city needs modern urban and regional transportation networks to breath do you not? Author's sense.

\section{Urban development needs transportation infrastructure}

This paper discusses the link between urban planning and suitable transportation networks. Iran approved national plans to build new towns. The urban planners targeted to settle increasing numbers of people in the new towns. However, many new towns failed to be attractive enough to accommodate the planned number of people. Lacking of well-designed and functional urban infrastructure, particularly traffic networks are one of the leading factors causing the stoppage. So, the lack of traffic and transportation networks in the new towns caused problems for their inhabitants and declined the people's willingness to live in the new towns. At the same time, the new towns lack regional corridors to connect them to neighboring cities and communities. My hypothesis is that new towns without including urban traffic infrastructures and regional transportation networks will not enable us to settle the people successfully.

\section{Background of the problem}

The role of transportation infrastructure is a known historical fact. The world history on urbanization shows people planned and built the cities near possible water channels and overland roads to make contacts with other communities [1]. Despite the historical advice the relationship between transportation infrastructure and the development of new towns has become complex in Iran recently. A major reason causing the complexity is the simultaneous increase of population and urbanization. When the demand for communication and the transportation infrastructure is a basic human need for the growing regional population, the traffic network infrastructure should provide the means for communications and transitions of ideas, wealth, and services among the urban inhabitants. Surprisingly many new towns in Iran stay without transportation infrastructure. Because of urban crisis and social pressures, the urban and regional planners do not include planning of traffic and transportation infrastructure in the process of new town planning and design [2]. So, this paper recommends a suitable urban and regional transportation infrastructure network to overcome the problems of non-sustainability and nonattractiveness of the new towns. 


\section{Urban and regional transportation in the mirror of theories}

Transportation networks and sustainable development: Generally, sustainable development refers to a city's ability to meet its needs. Michael Kinsley understood the importance of the sustainability [3]. At the same time, many scholars believe that a sustainable development links strongly to suitable urban and regional transportation networks. Sometimes, despite good intentions to plan transportation networks, those good intentions are far from the real practice and many new built towns in Iran do not have proper access to traffic and transportation infrastructure networks [4]. When the transportation planning is so important to what does the transportation planning paradigm amount? [5]. Because of natural and environmental problems in Iran, the transportation network should cope with the regional conditions. Sumant et al. [6] suggest a new city model to reduce demand for transportation and so to conserve natural resources [6]. However, Sumant et al. [6] suggestion is not helpful in the case of new towns when many people demand to live there. Nevertheless, we have learned from the scholars that a significant view of the transportation model shall be the promotion of the sustainability [7].

Components of a generic transportation network: When scholars discuss on traffic and transportation infrastructure networks they name two views of infrastructures; hardware and software. Several parts of a traffic network are included in hardware infrastructure and others are in software. However, in this discussion as Fulmer [8] suggested I propose three significant parts of a generic network.

a. Infrastructures

b. Transport instruments

c. Operations refer to the actions

To plan and build both urban and regional transportation networks in the region this study needs to supply the three parts that Fulmer suggested.

Technical view of a traffic infrastructure network: The regions suffer from absence of knowledge, technology, experts and technological tools and devices. Obviously, knowledge and technology require investment in transport and traffic systems. Yuji et al state about the importance of knowledge, technology, and funding in transportation infrastructure suggested a rational model [9]. The Yuji model helps overcrowded populated regions with rapid increase in the number of automobiles on the roads to plan logically. Flyvbjerg et al. [10] noticed the importance of the futures studies to plan the technical features of a transportation network $[10,11]$.

The model of a transportation network and the process of its planning and design include both ex-ante and ex-post analysis phases. While ex-ante studies contribute to the planning of the transportation networks ex-post analysis involves monitoring of the results [11]. Thus, the technical features of the traffic model should analyze and consider both the technical state of the present and understanding the future needs as well.

\section{Laminar flow of urban traffic}

One basic urban problem that creates many urban traffic problems such as pollution, and traffic jam is the narrow and short space passages in the regional cities. Fluent traffic requires scientific, modern, and sustainable infrastructure networks. Such networks involve the design of roomy streets and squares, design of traffic control installations including traffic signals, signs, and pavement markings. Traffic flow management is one part of laminar traffic flow in new towns. Increasingly, planning of fluent traffic needs intelligent transportation systems with engineering disciplines. To make a fluent flow of traffic in every new town needs to decide the measures pertaining to the boulevards, streets and other passages. Since the transport model developed in this paper includes a regional freeway, we will also discuss fluent flow of traffic on freeways. The model is aimed to cut the frequency and severity of accidents. Traffic collisions are at an alarming frequency now in the region [12]. The above-suggested program is useful to prevent the current mortal traffic accidents.

The study tools should be used to plan an environmental friendly transportation network. Environmental urban traffic networks need spacious avenues, streets, and boulevards with tall trees along their two sides to beautify the new town and combat the hard climate. Additionally, the even topography, environmental reasons and expensive fuels suggest that there should be an agenda to use bicycles in the towns. Pucher [13] suggested that an important step to increase cycling is having special lanes for cyclists.

\section{Rationality and functionality of transportation networks}

Generally, a rational model has logical and technical views and uses the analysis of quantitative data to decide the best characteristics in the new transportation infrastructure network. The area of rational modeling is wide although it is both feasible and suitable to the new towns [5]. To plan a functional model of transportation network many scholars recommend the pentagon model [14]. The pentagon transportation system assumes that a high quality functional fluent traffic encompasses of five above named wares.

\section{Urban and Regional Transportation in Practice}

\section{Place of Ramshar new town in Iran}

Ramshar is situated 40 kilometers south of Zabol city, along the Zabol-Zahedan road. Sistan is regarded as the continuation of the Helmand region most of which is in Afghanistan. Ramshar is close to the Afghanistan border, see Figure 1 one below:

Ramshar is situated on an even plain although to the east direction at about 25 kilometer away there are some small hills. The new town is limited to the Lootak plain and has the cities of Mohammadabad and Zabol respectively in the north direction. From the south direction, the new town is open until the bifurcation of Zabol-Zahedan. From the western side the domain of Ramshar continues until the mountains of Nehbandan. From the east 
direction, the new town is close to the sand dunes frontier of Pakistan and Afghanistan. Ramshar needs particular attention in the urban traffic planning aiming to connect it to the peripheral cities and the main regional road network.

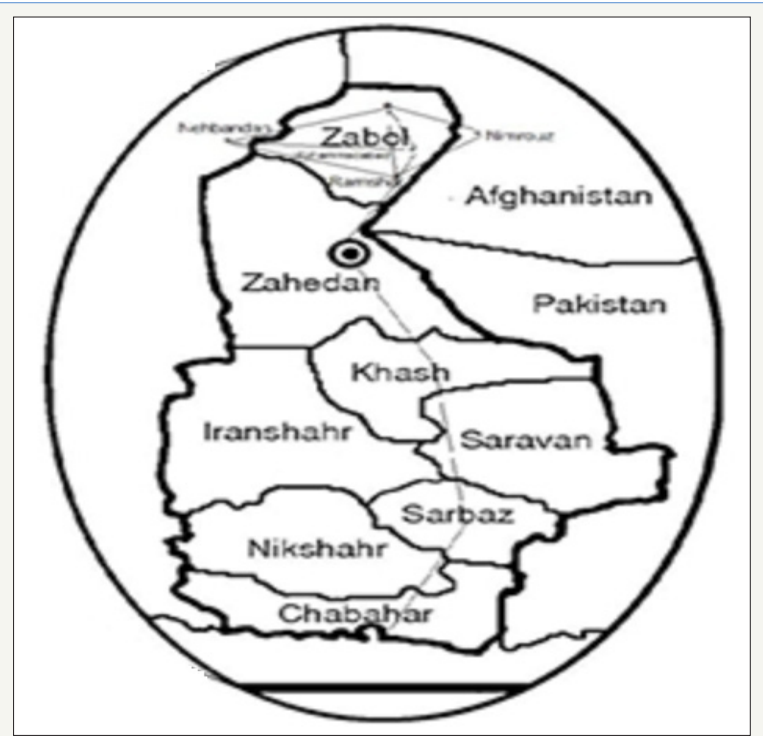

Figure 1: The geography of the Ramshar region.

Source: Shahraki [5]

\section{Ramshar needs urban and regional transportation networks}

Ramshar is on the main relational road of Afghanistan-NimrouzZabol-Zahdan-Chabahar. This main relational road connects the major populated centers while it lacks the necessary technical, security and comfort standards. Access to Ramshar requires improvement of the existing narrow small road. The idea is to plan and build a freeway from the junction of Zahedan-Nehbandan to Zabol and to Nimrouz city in Afghanistan aiming to accommodate the present and future transport demands of the region. Many serious traffic accidents along the regional road network make driving very hazardous. The Iranian traffic commission reports that every year 25000 people are being killed and 600000 injured in traffic collisions when 150000 of them remain crippled. The commission suggests that one major reason to such figures is the non-standard roads and streets [15]. Field observations for the thesis project recognized that there is a strong opinion to build a corridor connecting Ramshar to the city of Nehbandan, via the western plains. Obviously, the link will give a faster connection between Ramshar and Nehbandan.

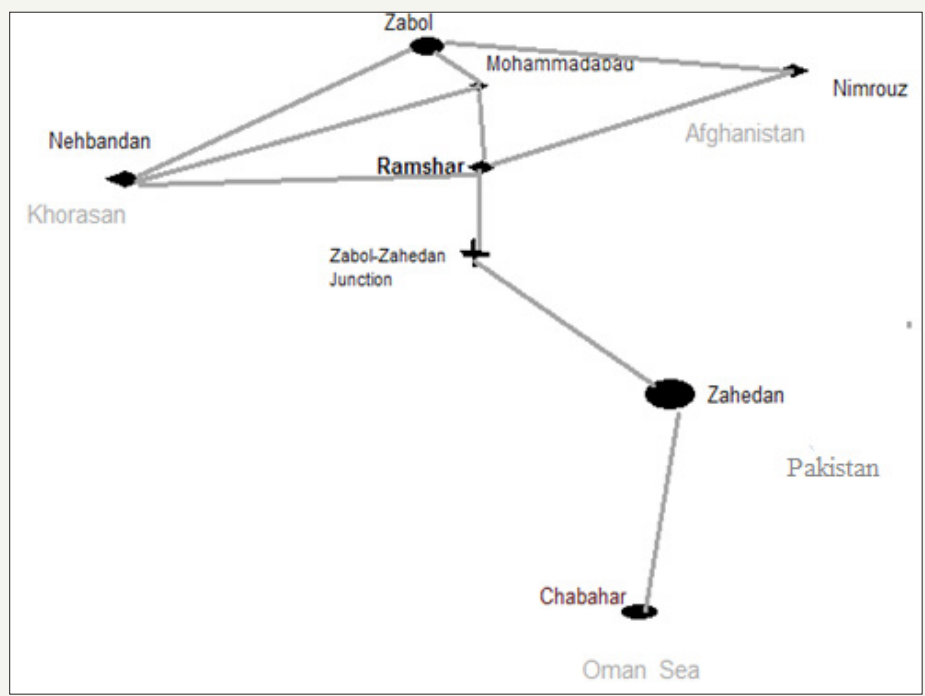

Figure 2: A graph of the suggested regional transportation network.

Shahraki[5].

Additionally, Ramshar needs access to small border towns and villages such as Zahak, and Miankangi via a new frontier line. Since the regional strategic plan considers the Sistan plain as a free economic zone the freeway of Nimrouz-Zabol- Zahedan- Chabahar would give a secure and fast access from Afghanistan to the Oman Sea; see a graph of the proposed corridor in Figure 2. 


\section{Transport model of Trans Sistan Network, TSN}

Let us to consider the northern part of the above graph as a regional transportation network model. Since this traffic and transportation planning study is the first one in this region I have named it the Trans Sistan Network, TSN. I will describe and analyze a system here. As Batten said, mathematically a very convenient way to represent this kind of system is as a graph [16]. An abstract graph is simply a set of nodes together with a set of edges connecting various pairs of elements in a system. Figure 2 exhibits a graph of the TSN model consisting of nodes and edges.

Vickerman [17] analyzed the impact of the Trans-European Network and concluded that the corridor affected the economy and security of the region positively, particularly in the eastern European countries; sees [17]. In line with Vickerman [17] it seems likely that the TSN will impact southeastern Iran positively as well. One perspective of the TSN is the analysis which proves its contribution to the security and sustainability of the region. A significant characteristic of the region is the lack of sustainability and security. For the current application the data that exhibited the necessity of the TSN have been gathered.

\section{Two parts of the Trans Sistan Network, TSN}

The TSN model is developed for the urban traffic infrastructure in the new town of Ramshar and a regional transportation corridor. Generally, the theme of fluent traffic in any new town should analyze the following two pivotal problems, the urban one and the regional one. The first problem is to forecast the traffic of automobiles, problems of flow in the streets and squares, problem of parking, subjects on railroads, train stations, problems of bus, taxi stations, and cyclists. The second one is to solve the problems related to sidewalks, pedestrian bridges, safety, and health of pedestrians.

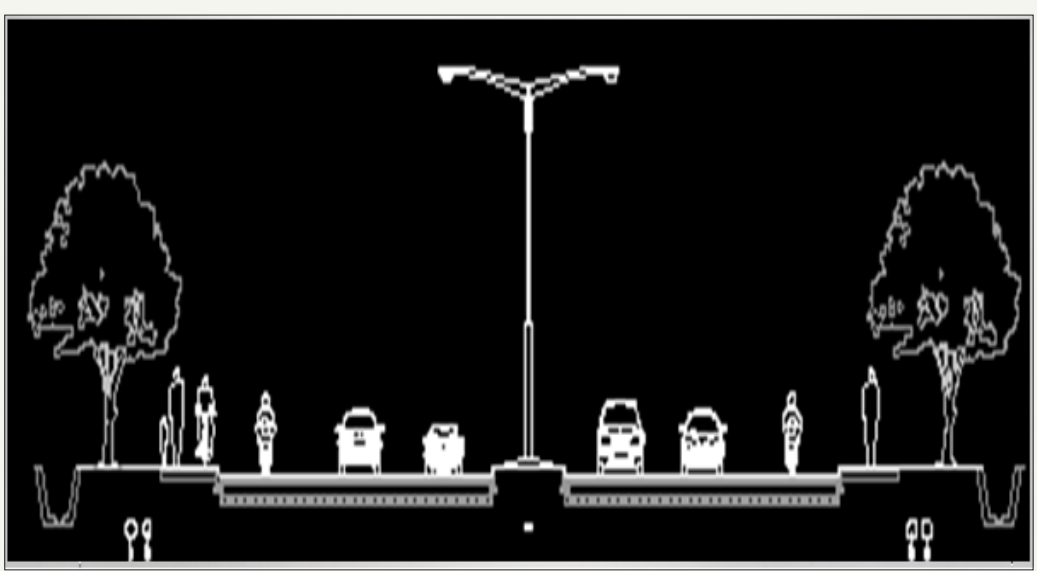

Figure 3: A transverse sectional perspective of the corridor at point of along the road.

Source: Sketching by the author.

The regional transportation network is to increase connections and movements among regional villages, towns, and cities also connecting the region to the main national traffic systems and neighboring countries. The regional corridor will break the isolation of the new town of Ramshar. However, planning and building of the regional corridor must follow the advanced technical and environmental standards and codes of freeways. As said earlier,

\section{Technical Characteristics of the TSN}

since the region suffers from sand dune typhoons the region will need to protect the freeway with the help of tree plantations. The freeway should also include buffer lines for cyclists for the villagers to use to travel by bicycle and motorcycle between nearby towns and neighborhoods. Figure 3 depicts a sectional perspective of the particular characteristics of the proposed regional corridor.

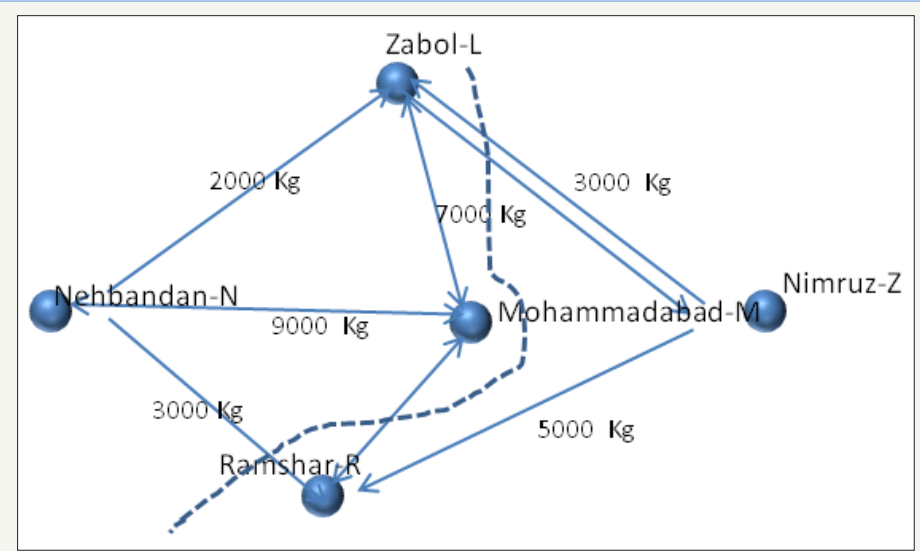

Figure 4: Graph of the region's road network. Source: Shahraki[5]. 
This study calculates the traffic capacity for the corridor that is particularly significant to decide its technical characteristics and its measurements. Figure 4 shows a graphic representation of the Trans Sistan Network with capacities on links.

Suppose that there is a flow of goods traffic from one station to the other one for example from southern Khorasan to Afghanistan. The capacity limits the flow on every edge in the graph. As you see on the graph, each edge of the network has a denoted number based on the experimental statistical data that has been provided. For example, see the path of Nehbanadn-Zabol with a transported $\mathrm{kg}$ /hour goods traffic capacity. The purpose is to find the largest weight of goods that can be transported between nodes. So, it needs equations stating that the flow on any edge does not exceed the capacity for the edge, and equations showing the sums flowing into and out of the nodes. The TSN system provides an automated model to perform these calculations.

The capacity for passenger traffic in every part of the corridor could be calculated similarly. The method will contribute to deciding the technical characteristics of the corridor. The calculations suggest that the corridor/freeway on its major part has the two crossing bands on every direction. Additionally, on each side a three metric wide space is needed to design a sidewalk and a cycling line. The freeway would have tall trees to prevent winds, sand storms, and noise pollution. On both two sides of the freeway necessary facilities such as gas stations and resting buildings will be built which by increase or decrease speed ramps and different level intersections are affordable. The duty of the freeway is to connect the major centers of the Sistan plain. When freeway passes more regional towns and villages, it acts as a regional corridor.

\section{Impact of the TSN in the region}

The clearest consequences of the proposed corridor are a change in the lifestyle, declining of animal use for cargo transport and use of new vehicles and transport facilities. The corridor will presumably reduce the number of Sistan traditional horses. The corridor encourages the regional traders to use legal freeways instead of natural dangerous paths. The expectation is that current irregular travels will be regulated. The corridor shortens travel distances and travel times. Finally, the corridor increases the number of movements and transports in the region.

The corridor increases private trips and people will spend more money for their visits in other cities. Right now, many people travel to Zabol and Miankangi from other provinces to shop and use the advantages of the free economic zone. The proposed corridor will ease the travels and the trade. When there are valuable, historical buildings and ancient cultural works in Sistan the corridor will increase the number of tourists and the number of job opportunities. The corridor will increase the price of land and property in the region. The collaboration among the neighboring countries is likely to grow and it will boost the regional economy.

Since the ecologic system of the region is totally related to the Hirm and River and its branches and to Hamoon Lake, the planners shall take care when placing the bed of the corridor. Everywhere the corridor crosses the watersheds and water resources they will have to consider particular civil engineering remedies to cut the detrimental effects. The corridor remains a wide harmful impact on the lands. The bed of the corridor occupies approximately 2400 hectares. Since the region is a cultivated area, the drawing of the project line and the localization of the stations and other required facilities should be done in ways to harm agricultural farms as little as possible. The corridor will generate air pollution and noise when the regional traffic number increases.

The corridor is useful for the sustainable development of the Sistan part in Afghanistan as well. The corridor will have positive effects in provinces such as Nimrouz, Helmand, and Zabol in Afghanistan. The corridor eases commercial and cultural mutual relations with Pakistan and Bangladesh as well.

The corridor causes growth of legal travel and transport of approved goods in the free economic zone of Sistan. The corridor contributes to the enforcement of laws in the free economic zone. Thereupon the conditions will become better for domestic and foreign investments. Additionally, passengers and business people from adjacent countries can get access to the free sea via Chabahar harbor and other provinces of Iran are using this corridor. The corridor will change the cultural and economic life of the local people. So, the security of the region and the chances for a sustainable development will improve.

\section{The Trans Sistan Network Makes the Region Sustainable Field studies}

To investigate the hypothesis of how much the traffic network contributes to_sustainable development of the region we argue the profitability in terms of security and sustainability. The data on the regional traffic have been gathered in Table one. The table shows the estimated numbers of buses, minibuses, private cars and trucks. The numbers are provided by typical direct sample observation on Zahedan-Zabol road, near the new town of Ramshar, round the clock at various times for a time period.

Table 1: Average number of traffic per hour

\begin{tabular}{|c|c|}
\hline Type of Vehicle & Average Number Per Hour \\
\hline Bus & 1 \\
\hline Minibus & 0.25 \\
\hline Private car & 30 \\
\hline Truck & 1 \\
\hline
\end{tabular}

Reference for data: Shahraki [5].

Table 1 show that regional people travel by private cars instead of public transportation. Based on the observation we consider 30 passengers per one buss hourly, ten passengers per one minibus per hour, three persons per one private car per hour and 15 tons of cargo per one truck per hour. Because of the increasing demands of public and private economic sectors to reach the Oman Sea and the increase of the regional population the study predicted a ten 
percent passenger increase and 18 percent freight transport raise in case of corridor building. It has been supposed that the corridor will increase the tourists by 20 percent. Other positive effects will remain as table two reports.
Table 2 shows the improvement of every impact if the TSN will be built. Now it is possible to discuss the costs of the corridor. The main source in our arguments is an earlier published book in Persian, Strategies to develop Ramshar, containing an econometric analysis of the new town [5] Table 3.

Table 2: Impact with and without corridor calculated for one year.

\begin{tabular}{|c|c|c|}
\hline Type of Impact & Without the Corridor & With the Corridor \\
\hline Passenger traffic/number/year & 376680 Passengers & 414348 Passengers \\
\hline Cargo transport/kilogram/year & $129600000 \mathrm{~kg}$ & $152928000 \mathrm{~kg}$ \\
\hline Declining of travel time/minutes & 210 Minutes & 120 Minutes \\
\hline Attracting tourists/person/year & 0 & 120 Tourists \\
\hline Increasing of the regional productions/kilogram/year & 0 & $300000 \mathrm{~kg}$ \\
\hline Increasing of jobs/number/year & 0 & 100 Jobs \\
\hline Growth of international collaboration/percent t/year & 0 & $4 \%$ \\
\hline Population growth in Ramshar yearly & 0 & 300 People \\
\hline Improving of the quality of lands $/ \mathrm{m}^{2}$ & 0 & $20000000 \mathrm{~m}^{2}$ \\
\hline
\end{tabular}

Source: Shahraki [5]

Table 3: Benefits of the corridor

\begin{tabular}{|c|c|}
\hline Nr. & Type of Benefit \\
\hline 1 & Increase of passenger traffic \\
\hline 2 & Increase of cargo transition \\
\hline 3 & Decline of travel time \\
\hline 4 & Growing number of inhabitants in Ramshar \\
\hline 5 & Tourist attraction impact \\
\hline 6 & Creating job opportunities \\
\hline 7 & Increasing international cooperation \\
\hline 8 & Improving attraction of region by the corridor \\
\hline 9 & \\
\hline
\end{tabular}

Reference of data: Shahraki [5]

\section{Costs}

Costs to buy land for the bed of the corridor: The bed of $200 \mathrm{~km}$ long and 60 meter bred of our corridor covers 1200 hectares land. The price of the land shall be paid.

Costs to build the corridor: The prices to build the freeway that we need according to the current regional fees should be financed.

Costs for the maintenance: This item depends on the future urban management and conditions. However, we must calculate this item as well.

Benefits of the TSN corridor: Table three reports the types of benefits which the construction of the TSN will provide.

Cost benefit balance of the corridor: Well, there are the necessary facts to claim that the construction of the TSN is helpful indeed to make the region sustainable and secure. A monetary calculation has been made earlier and it subtracted the total cost from the total benefits of the TSN. A ten profit ratio has been experienced initially, a very high profit indeed [5]. This research recognized that the alternative of building corridor is helpful both economically and socially.

The hypothesis of this paper claimed that the building of the TSN would contribute to traffic safety, economic growth, and sustainability of the region. As you have seen the analysis verified the hypothesis about the benefits of the TSN [18-37].

\section{Conclusion}

This paper states that the regional transportation corridors and urban traffic infrastructure networks make new towns sustainable and functional in Iran and similar regions in the world. The paper studied general theories on linkage between sustainable urban planning and design and transportation infrastructure. Both the theoretical studies and the case studies demonstrated that the planners should not plan and build a sustainable and attractive new town without adequate urban traffic infrastructure and an adjoining regional transportation network.

This research gathered the necessary data by a statistical sampling method and by direct gauging of traffic capacity. Then, it analyzed the data and applied it to the planning of the TSN in the region. The planners, civil engineers, and decision makers in the region have not considered the effects of adequate suitable traffic infrastructures for sustainable development of the new towns. There is a lack of feasibility studies, socioeconomic research and nobody has been predicting future needs. In this perspective, the paper suggested the model of the Trans Sistan Network, TSN, for the area of the Ramshat's new town. The model proposed is preliminary and can be seen as an indication of a direction of research-based practice needed in new town development in Iran. 


\section{References}

1. Jiangping Z (2012) Sustainable transportation in the US: A review of proposals, policies, and programs since 2000. Published in the International Journal of Frontiers of Architectural Research 1(2): 150156.

2. Elshimy H (2011) Sustainable development criteria set for the transportation planning. International Journal of Procedia Engineering 21: 1042-1055

3. Kinsley M (1997) The Economic Renewal Guide. A collaborative process for sustainable community development. Snowmass, CO: Rocky Mountain Institute, Colorado, USA

4. Rosales N (2011) Towards the modeling of sustainability in urban planning: Using indicators to build sustainable cities. Published in the International al Journal of Procedia Engineering 21: 641-647.

5. Shahraki AA (2005) Strategies to develop Ramshar, Iran's company to new towns constructing, publications in Persian, Tehran, Iran.

6. Sumant S (2011) New city model to reduce demand for transportation. International Journal of Procedia Engineering 21: 1078-1087.

7. Transport Planning Society (2006) Draft National occupational Standards for Transport Planning.

8. Fulmer J (2009) What in the world is infrastructure?

9. Yuji I (2011) The Application of cloud computing in transport planning using interactive 3D version simulation technology.

10. Flyvbjerg B (2005) How are demand forecasts in public works projects? Journal of the American Planning Association 71(2): 131-144

11. Johnston A (2004) The Urban Transportation Planning Process. In: Genevieve G, Susan H (Eds.), The Geography of Urban Transportation, the Guilford Press, USA, pp. 115-138.

12. Cornell Local Roads Program (2009) Road Safety Fundamentals, Ithaca, New York, USA.

13. Pucher J, Ralph B, Mark S (2011) Bicycling Renaissance in North America? An update and re-appraisal of cycling trends and policies. Published in the international journal of Transportation Research Part A45: 451-475.

14. Nijkamp P (1994) The strategic role of new infrastructure networks in Europe. Summer University of Stockholm, Sweden.

15. Traffic report (2008) Commission for traffic and transportation, Iran's Islamic parliament, Persian published, Tehran, Iran.

16. Batten D, Casti J, Thord R (1995) Networks in action, published by Springer-Verlag.

17. Vickerman RW (1995) The regional impacts of Trans-European networks. The Annals of Regional Science 29(2): 237-254
18. Andersen K, Karlström A (2001) The regional development impact of the Oresund Bridge. KTH, Stockholm, Sweden.

19. Asian development bank (2013) ADB.

20. Das S, Levinson D (2004) A Queuing and Statistical Analysis of Freeway Bottleneck Formation. ASCE Journal of Transportation Engineering 130(6): 787-795.

21. Gharib F (2005) Street network in urban design. Tehran, Iran.

22. Hedman R (2001) Fundamentals of urban design. Tehran, Iran

23. Hermann K (2001) Principles of designing of cycling lines. Tehran, Iran.

24. Huttonm B (2007) What's the purpose of an 'integrated transport policy? Weekly magazine of Local Transport Today, UK.

25. Kell J, Perkins C (1992) Fundamentals of Traffic Engineering, (13 ${ }^{\text {th }}$ edn), Institute of Transportation Studies, University of California, Berkeley, California, USA

26. Levy JM (2011) Contemporary Urban Planning, Longman,Boston, USA.

27. MC Cord R (2002) Planning urban infrastructure. Tehran, Iran.

28. Ministry of housing and town building (2001) Strategic plan of new town of Ramshar, volumes 1-8. Tehran, Iran.

29. Mogharrabi A (2005) Integration issues with new town development and transportation planning. Farsi, Tehran, Iran.

30. Muchukuri E, Grenier FR (2009) International Journal for Equity in Health. International journal for equity in health 8: 1-16.

31. Ning C, Hoon D (2011) The sustainable development strategy of tourism resources. Exploring the feasibility for Weihai City of China. International Journal of Procedia Engineering 21: 543-552.

32. Oluwafemi 0, Yinusa AJ, Mutiu AA (2013) Development of an advanced public transportation system in Ilorin, Nigeria. Department of Civil Engineering, University of Ilorin, Nigeria. International Journal of Alexandria Engineering 52(3): 447-454.

33. Rapaport E (2002) Contributions of system analysis of land use and transport planning for air quality, doctoral dissertation.department of infrastructure, KTH, Stockholm, Sweden.

34. Shahraki AA (2014) Sustainable new towns in Iran: Reflections on problems and practices of urban planning and design using case studies.

35. Southern A (2006) Modern-day transport planners need to be both technically proficient and politically astute.

36. Transport Planning Society (2006) Draft National occupational Standards for Transport Planning.

37. Wafaa Abdel Monem A (2005) A case study of Al Sadat new city in Egypt, Cairo University, Egypt.
Creative Commons Attribution 4.0 International License

For possible submissions Click Here

\section{Submit Article}

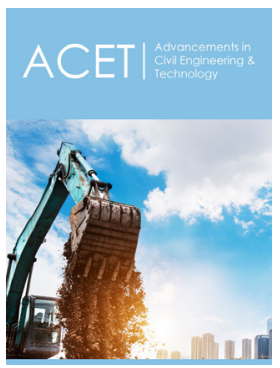

Advancements in Civil Engineering \& Technology

\section{Benefits of Publishing with us}

- High-level peer review and editorial services

- Freely accessible online immediately upon publication

- Authors retain the copyright to their work

- Licensing it under a Creative Commons license

- Visibility through different online platforms 